This article was downloaded by: [New York University]

On: 03 May 2015, At: 23:41

Publisher: Routledge

Informa Ltd Registered in England and Wales Registered Number: 1072954

Registered office: Mortimer House, 37-41 Mortimer Street, London W1T

3J H, UK

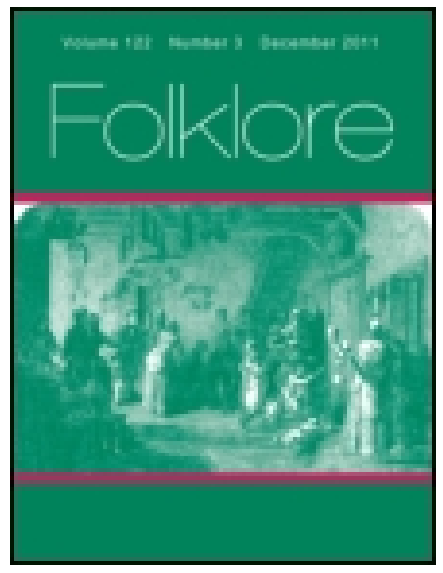

\title{
Folklore
}

Publication details, including instructions for authors and subscription information:

http:// www. tandfonline.com/loi/ rfol20

\section{On Some of the Earliest Existing Races of the Plains of South India}

Mr. F. Fawcett

Published online: 14 Feb 2012.

To cite this article: Mr. F. Fawcett (1894) On Some of the Earliest Existing Races of the Plains of South India, Folklore, 5:1, 18-38, DOI: 10.1080/0015587X.1894.9720200

To link to this article: http:// dx. doi.org/ 10.1080/0015587X.1894.9720200

\section{PLEASE SCROLL DOWN FOR ARTICLE}

Taylor \& Francis makes every effort to ensure the accuracy of all the information (the "Content") contained in the publications on our platform. However, Taylor \& Francis, our agents, and our licensors make no representations or warranties whatsoever as to the accuracy, completeness, or suitability for any purpose of the Content. Any opinions and views expressed in this publication are the opinions and views of the authors, and are not the views of or endorsed by Taylor \& Francis. The accuracy of the Content should not be relied upon and should be independently verified with primary sources of information. Taylor and Francis shall not be liable for any losses, actions, claims, proceedings, demands, costs, expenses, damages, and other liabilities whatsoever or howsoever caused arising directly or indirectly in connection with, in relation to or arising out of the use of the Content.

This article may be used for research, teaching, and private study purposes. Any substantial or systematic reproduction, redistribution, reselling, loan, sub-licensing, systematic supply, or distribution in any form to anyone is 
expressly forbidden. Terms $\&$ Conditions of access and use can be found at http://www.tandfonline.com/page/terms-and-conditions 
ON SOME OF THE EARLIEST EXISTING RACES OF THE PLAINS OF SOUTH INDIA.

BY MR. F. FAWCETT.

South India, a field second to none in value for investigation of the human animal in relation to his conditions, the early course of his civilisation, and the like, is almost an unknown country. If ever there was a country where the value of the science of folk-lore can be fully exemplified and justified, here is one, full of the strangest medley of races.

It is noteworthy that the usually scattered communities of the earliest races of the plains of South India are invariably either distinctly criminal or entirely harmless. All are, even now when the schoolmaster is very much about, almost to a man unlearned. They are not the agriculturists, or the workers in metals, or the weavers, or the traders, but the people who prey upon these ordinary and useful members of society. They are also the hunters. The nomadic Yanadis, Erakalas, Koravas, and the Kullens are some of these depredators and hunters, who are responsible for by far the greater part of the crime of the country. On the other hand, there are the Pullers of Tinnevelly in the extreme south, who are perfectly harmless and inoffensive, though perhaps deserving the lowest place on the list for culture and intelligence.

There is, so far as my research goes, amongst the aboriginal races of South India of the hills or plains, no trace of a beneficent Deity, who, wherever we meet him, is of Hindu, or, we might say, Aryan origin.

I propose to attempt some description of the Wadders and of the Kullens, both of the class Dravidian. First, the Wadders, more or less nomadic, found nearly all over South India. They are somewhat of an exception to the criminal class, in that their life is not entirely criminal. They are the earth-workers, the diggers of all kinds of carthworks, tanks, wells, railway embankments, canals, and 
so on. Men, women, and children work all together. They also do the rough stone-work, blasting and carting rough stone for building or for roads; most valuable allies when excavating cromlechs and the like, for their practical knowledge is wonderful, and they are right good workers. Altogether throughout South India they number about half a million. Physique good; character bold and somewhat desperate. Their dress is that of the lower Sudra castes. The trident-like mark of Vishnu is marked with white and red clay powders on the forehead, arms, and breast of the men. Women wear bangles on one arm only. As is well known, the Hindu marriage token, or weddingring, is the talli, a circular bit of thin, flat gold, about the size of a shilling, worn on a string round the neck. The Wadders' marriage token is a string of black beads. They have a legend that once on a time a tali was not ready at the time of a marriage, and a string of beads was substituted for it. It is, however, likely that the Hindu token was never adopted.

The wearing of beads, usually of white clay or shell, to express some attachment or devotion to certain deities, is common in South India, and necklaces of this kind (exhibit 2), which answer some religious as well as ornamental purpose, are common.

Socially, the Wadders rank with barbers, above the Parias and lower castes. They eat all animal food, and drink freely of liquor.

Rats, and even jackals, they will eat. I remember how the Wadders about Bangalore spoiled our hunting by eating up numbers of the jackals and foxes.

Criminal gangs of these Wadders-all are criminally inclined-are quite regardless of the bodily pain they may inflict. Children are case-hardened early, and taught lying. which, strange to say, is not natural; but they turn out clumsy thieves.

- A game the men play is a sort of rehearsal of their exploits in the dark, and is intended to develop their senses as well as their skill. A man, blind-folded, stands in the 
centre of a circle of his comrades. One makes some noise. The man in the centre must instantly throw a stone at the man who made it, or, at any rate, in his direction. When the stone is thrown the wrong way the thrower is chaffed unmercifully.

Thus they learn to mark with a stone anyone approaching in the dark to disturb their criminal operations, knowing exactly where a man is by the sound of his voice or by the noise he makes in walking.

They have never been known to betray a friend or confess a crime.

Salutations they have none; but when one arrives from a long journey he is given water to wash his feet. If he bears bad news, as of a death, he must not enter a house until he has been taken to the liquor shop, and given plenty of liquor to drink.

Their money is squandered in drinking and gambling.

Sons inherit their father's property, the share of the eldest being the largest. Daughters and mothers are sometimes given a little of the property, but they have no intrinsic right to any.

There are two tribes: (1) the supposed descendants of Gunju Raju, a king ; and (2) the supposed descendants of Svanna Mádva, his minister ; each sub-divided in gôtrams, or inter-tribal divisions. Margosa tree, cloth, wall, cot, mud-pot, basket, axe, patience, tamarind,-naked, cheat, stone, hedge--are the names of some of these, derived, so they say, from some observed connection between the folk of a gôtram and some physical object or characteristic trait. All within ( 1 ) are considered to be brothers and sisters, and cannot intermarry ; so they must marry into (2), who for the same reason must marry into (I); (2) is inferior to (1).

In all tribal or folk gatherings and marriages there is a man of (2) called the "Saduyagadu", whose office it is to attend as may be required, make arrangements and so on, for which he receives regular fees. He has an assistant, a 
man of (1), descended from the king-by a concubine. Any offence offered to either of these when on duty is punishable by fine.

Offences of the nature of slight personal injury, refusing to pay a small debt, and such like, are settled by a tribal court, the injured párty receiving compensation. One refusing to abide by the sentence which is awarded is boycotted-cannot draw water from the well, no one will eat with' him or enter his house, no one will give him fire, and he is disallowed the privilege of the general assistance of the caste should he require it.

"Where there are ten men God is present", is the usual formula of oath, which reminds us of "Where two or three are gathered together, etc."; in important cases a man swears by a child which he holds in his arms.

The ceremonies connected with marriage make it rather an elaborate affair. First there is the betrothal, for which an auspicious day is chosen by consulting a Brahmin astrologer. The bridegroom is taken by his parents to the bride's hut-a small, circular, thatched construction of mud walls and conical roof, like a large beehive.

"Saduyagadu" spreads out a sheet, around which the parents and near relatives of the bride and bridegroom sit on mats, bridegroom facing east. When ordered by the company, "Saduyagâdu" brings betel, flowers, etc., and places them on the sheet. Bridegroom then produces six four-anna pieces (about the size of sixpence, but at present worth much less), one of which he gives to the parents of the bride for toe-rings and a string of black beads, the marriage tokens, and the other four pieces he gives into the custody of the "Saduyagadu", who keeps them towards the wedding feast. The parents of both parties stand on opposite sides of the sheet; "Saduyagâdu" puts betel nuts and flowers in their hands and asks them to declare their consent for the marriage of their offspring; this they do, and the marriage day is fixed. But if there is a death in either family, or among their cattle, or if either party 
sees a snake in the house, or is stung by a scorpion, or suffers under any serious calamity before the marriage day arrives, the betrothal is cancelled and the parents of the bride return the four-anna piece to the bridegroom. The food and liquor consumed by all present at the betrothal are paid for by the bridegroom.

The marriage takes place where the bride lives; a shed, roofed over with mango and some other leaves, being erected for purposes of ceremonial in front of her hut. Mango leaves tied across the streets and doorways on occasions of festivity are very common throughout the country. They are considered to be decorative, as well as conveying some subtle auspiciousness. In the afternoon the bridegroom invites the caste-folk to his wedding, presenting each man, woman, and child with three betel nuts, five betel leaves, one-sixteenth of a measure (which is about $2 \mathrm{lb}$.) of rice, and one-eighth of a measure of green gram. The gram is cooked and eaten. After dark the Saduyagadu escorts some married women to fetch water in two pots from a well, at which they are presented with red powder, some saffron, and betel leaves. It is impossible to stop here to consider the general use of saffron and its substitute, turmeric, in Hindu ceremonial. Suffice to say its use conveys some subtle meaning underlying its colour. Music is played while they are going and returning. The pots of water are smeared over with lime, and carried by the women, while a canopy of cloth, tied at the corner to sticks, is held over their heads by four men to the house of the bride, where bride and bridegroom are seated in different apartments (of a few square yards, the hut being very small), on the head of each a sheet, from the centre of each sheet is a thread, the end fastened to a bit of saffron laid on a heap of rice, and in front of each is placed one of the pots of water. The married women then oil the pair about to be made happy from head to foot, first the bridegroom and then the bride, and after this performance the pair are 


\section{Early Races of South India.}

seated side by side, each on a wooden mortar (an upright log of wood with a hole in the top, used for pound. ing grain), while the caste-folk chaff them in terms neither remarkably delicate nor subtily allusive. They are separated after awhile, and dressed in new cloths. A woollen thread, to which is fastened a bit of saffron, is tied round the left wrist of the bride, and the same is tied round the right wrist of the bridegroom, who is at the same time armed with a dagger. Again they are brought together, the corners of their clothes are tied, and, holding hands, they enter the bride's room, while some songs are sung; in a few minutes they are once more separated.

At midnight, the Saduyagâdu goes off with a torch and procures a branch of a certain tree which he fixes firmly in the ground in front of the bridegroom, brings a wooden mortar, and with a cloth that has been worn by the bridegroom, ties it to the branch. The use of the wooden mortar in England for quite another ceremony is no doubt well known to you. Under date 1677 , I see that at Sandwich, Isle of Thanet:- " A woman carries the wooden mortar throughout the town, hanging on an old broom upon her shoulder, one going before her tinkling a small bell, for abusing Mrs. Mayoress."

The pots of water, it should be noted, must not on any account be touched by anyone, nor must the lamps be extinguished. So important are these particulars, that a certain individual is told off to look after them.

Between 2 and 3 A.M. the bridal pair are seated in front of the branch, and in presence of all the caste-folk the bridegroom ties the string of black beads round the bride's neck. They pour rice over each other, and the elders pour some over both. This rice is retained for the feast to follow. The bride is removed to her chamber, and the bridegroom is asked to draw the branch out of the ground-a test of his strength which, if he is unable to fulfil, he is ashamed, and it is done for him.

Next morning all regather, and the bridegroom gives 
the bride's parents (for the bride) a nose-ring and eight rupees, the oli or purchase-money for the bride, and distributes some rupees (twelve at least) amongst his castefolk. The pair are again oiled and bathed, and they swear eternal fidelity to each other by pouring milk over each other's head. Again they are washed in warm water, a pot of which is brought for the purpose by each family in the convention; they are dressed and taken to the bride's room, a fowl being sacrificed at the threshold, and their foreheads marked with its blood ere they enter. But before they are given admittance they have to submit to another ordeal. The male members of the bride's family obstruct them, using language which is rather more forcible than polite. "You son of a whore, who are you? You cannot come in here, unless you call her beside your mother." "My pimps and slaves", rejoins the bridegroom, "I have purchased her, so she is not my mother." Conversation, illumined by sprightly wit of this kind, is bandied about, they enter the room, sit together awhile, and are yet again separated. The marriage is now complete. The pots of water are emptied over a green tree, and the pot that was in the bride's room is taken by the bridegroom, and the pot that was in the bridegroom's room is taken by the bride. The bridegroom takes his wife to his house, where he feasts his kinsmen, and afterwards retires with his bride in her hut.

Altogether the marriage affair is anything but a joke, and both parties are likely to remember it.

Girls are married usually after puberty, but they are sometimes married before it. Widows may remarry as often as seven times; but the second or after ceremony is not elaborate-a new cloth and six rupees to the woman and a good feed to the caste-folk settles the business. A second wife is allowed only with the first wife's consent, or, in the case of her refusal, when she is given a sufficient settlement.

There is nothing remarkable about the birth ceremonies. 


\section{Early Races of South India.}

The midwife is given a fee of four annas in the case of a $\mathrm{son}_{2}$ and two annas in the case of a daughter; her remuneration not being in proportion to her skill, but to the relative value of the infant she assists into the world. On the loth or 15 th day, mother and child are washed and adorned by the married women, who bring warm water, saffron, oil, etc., for the purpose, and the mother distributes betel-a conventional civility, like offering afternoon teaand prepares a meal for all present.

The dead are usually buried quite naked, the cloths being discarded at the grave. Leaves are spread over the bodies of women before the earth is filled in. Grain and other food and burning camphor are always left at the grave. If a death takes place on an unlucky day, a fowl, a piece of iron, some salt, and some lamp-oil, are buried with the corpse. On the third day after death, food (flesh or fish and rice) is placed on the grave: or if the deceased was a child, milk is poured over the grave. The food is carried on leaves of the Bilva tree, Aegle marmelos; it is, held in great sanctity by, the Saivite sects, who will not on any account touch any part of it except for some holy purpose. Those who carried the corpse are fed on their return home.

The final ceremony for the dead is performed on the IIth or I $5_{\text {th }}$ day after death. A sheep is killed and the meat is cooked. If the deceased was a man, his widow, dressed in her best cloths and decked with jewels, is taken to the grave, where her bangles (the common sort usually, made of glass or a compound of wax) are broken, her necklace of black beads is removed, and, leaving some food on the grave, the widow is taken to a stream and bathed, and her toe-rings are removed and broken. "She is then given a new cloth, called a "widow's covering", and thenceforth she is not allowed to use saffron for personal adornment. When the deceased was a woman, her husband is treated in much the same style. After he has been bathed his 
moustache is shaved off and his waist-string is cut, and he is given a new cloth. This part of the ceremony is, for men and women, of a purificatory nature. The end of the ceremony is a good feed, on the sheep that was killed, with rice, etc., in which those present are supposed to be joined by the ancestors.

The spirits of ancestors are fed on all occasions of festivity. Venkatêsu, the Vaishnava deity of the famous Tirupati shrine-which is not very far from where these notes were made-to which pilgrims flock from every part of India, is their chief god, but the malicious village goddesses, Poleramma, Ellamma, and others, as well as ancestral spirits, are given the most attention. Ancestral spirits are worshipped and fed after every death.

The Margosa tree (Melia azadirachta) is likewise worshipped by the Wadders, whose regard for certain trees, a leaf, a branch, a fruit of which they will not touch, after which certain of their gotrams are called, seems to give the idea that totemism once obtained amongst them.

They have a tradition of their having been at one time a warlike people of the Lunar race, under their own king; and account for their dispersion and present condition of wanderers in the following manner:-Their king put to death several goldsmiths, because a man of that caste had misappropriated some of the gold which the king had given him to form into a jewel. Those who survived this act of tyranny resolved on revenge, and having retired into a fort which held some magical properties, induced the king and his minister to visit them in order to witness a play, and having got them comfortably seated on mats, blew them up with gunpowder, which had been concealed beneath the mats. For having thus successfully outrivalled Guy Fawkes they were obliged to flee in all directions; and so they became dispersed, and digging the earth is their occupation.

Unless we agree with $\mathrm{Dr}$. Oppert that gunpowder was known to the earliest inhabitants of India of whom we 


\section{Early Races of South India.}

have any written record, we must (rightly, I think) put down this legend to tolerably modern invention.

Now, for the Kullens, the "savage Collieries" of Orme. Bullen, by the way, is the Tamil word for "thief".

The stock to which they belong is divided as follows: Kullen, Ahambadiyan, Vambi Maravan, Kothali Maravan, Konddya-Kothai Maravan, and these are again subdivided. These do not intermarry, nor do they eat together; yet they are brethren. "We are one," they say. Altogether they number about a million and a quarter. Deducting the Ahambadiyans (who are much more Hinduised than the others, and much less harmful), there are about three-quarters of a million of Kullens and Maravans; and these live almost entirely by plunder. By crime positively, and by blackmail negatively. They are notorious as the principal exponents of gang-robbery, cattle-lifting, and thieving generally, in the three southernmost districts, Trichinopoly, Madura, and Tinnevelly. Unlike other marauders of the Presidency, they choose bright moonlight for their exploits on the road, and will not hesitate to attack Europeans. A year ago or so they stopped and robbed a train almost within hail of the military cantonment, Trichinopoly.

The men who engage in these affairs are not always impelled thereto by the heavy hand of want. Far from it. Maravan and Kullen farmers, who possess cattle, land, and all-sufficience for comfortable maintenance, will, for the pure love of the thing, go off on an expedition, assist in half-a-dozen gang robberies, and return richer perhaps by a few rupees. Neglect of these noble pursuits involves forfeiture of all favour from the women-who, of course, are more conservative than the men; and the individual who, thinking the game not worth the candle, wishes to confine his energies to agriculture, is compelled to do mischief, much as the old Border chief, if he dallied long at home at ease, found his spurs served up for dinner by the ladies of his establishment. Deep delight in 
robbery is in their blood, and they are not deterred even by exile to the Andaman Islands. The wild, weird howl of the Kullen women, when transportation to the "island beyond the sea" is the doom of a Kullen gang, shows how this form of restraint is appreciated.

Cattle-lifting is a perennial source of enjoyment. No matter where or how securely kept, cattle are never safe from the Kullens.

Their popular game is an exhibition of skill in dealing with savage animals. The most savage bull is led by ropes; a handkerchief is tied round its horns or round its neck. The victor is he who can get the handkerchief after the bull is let loose. Off it goes at full speed across country towards its home, from which it has been taken several miles. The Kullens dance in front of it like fiends, tempt it this way and that, lying flat on the ground to avoid being gored, dodging in every conceivable way, until at last one man seizes the handkerchief. Several villages join in this, and there is a jollification.

Their great skill in thieving, and their persistence in using it, enables the Kullens to levy blackmail far and wide. It is impossible, without being wearisome, to convey to you the tremendous power which this community wields, in the face of our strong administration of law and order. It is of great interest, for there is no doubt it is a very old affair ; and it may have grown out of methods of harassing the conquering races, who overran their country from the northwards. Of these, which now form perhaps the greater part of the population, the Telugu-speaking Naiks seem to be the best representatives.

Before the advent of the British, the Kullens and the Maravans were largely employed as watchmen, and guardians of the roads and villages. In consideration for certain grants of land, and so on, they guaranteed safety to travellers. I have a translation of a copper-plate inscription, given by the great King Tirumal Naik (began to reign 1623 ) to a Kullen chief, detailing the honours he 


\section{Early Races of South India.}

is to receive; how that, when he lays a certain blanket down in the villages, everyone will put so much in it; how that shepherds will give him certain dues, the first of the flock, on certain festivals; and even the betel-nut which his daughter chews is provided for by endowment of certain villages.

Our administration put aside these arrangements; and the Kullens, with their Maravan brethren, take what they can and how they can. They think it their right to do so. Their hand is against all outside their own people. No one is free from blackmail, no matter how high his position, European or native. It is levied in this way: every large householder must employ a Kullen, generally as an outdoor servant, and every small householder must pay a certain sum month by month.

Those who accept this unwritten agreement are safe, practically, from theft. Those who do not will suffer heavily. A regimental guard is no protection whatever from the Kullen thief; nor is attempt at personal defence. A gentleman tried this not long ago; placed a revolver under his pillow, and let it be known that he would shoot anyone who entered his room. The Kullens very soon took away the revolver, and when he awoke all his furniture was out in the garden. A man who can steal the sheet from under you, no matter how secure you make yourself, is a difficult customer to deal with.

For cattle driven to market, in carts or what not, tied up in a village for the night, regular kaval or watch dues must be paid, or the animals will certainly be lost. The most beautiful production of our administration in India is the Brahmin High Court pleader. The medium suits him beautifully, and he thrives, and absorbs oceans of rupees. He has glided easily through every conceivable examination in law; but he does not evade the Kullen, who bleeds him freely. Any request refused is at once followed by loss of something from his house. It is difficult to believe, but it is nevertheless true, that in some parts of Madura a 
Kullen will enter a house-of one of the best class of Sudra farmers-demand a good meal, and, having demolished it, will seek the last favours from his host's wife, and meet with no opposition. I have seen a whole village in abject fear of its Maravan watchman, whose courage and daring they felt.

I will just mention that the ingenious device of the notable Jonathan Wild, returning stolen property for a consideration, is in full vogue amongst the Kullens; indeed, it is the base of their success. "Tippucooly" is its common name. Setting fire to hayricks and houses-all thatched-is a common trick of the Kullens and Maravans, whereby to enforce their demands. Some people doubt the racial antagonism in Ireland. Here is something much older, and not less strong.

The courage and energy of the Kullens and Maravans seem to mark them as excellent material for soldiers-and so they are ; but their lawless, disloyal character makes it impossible to use them in this way, as a separate corps at any rate, even if they could be got to enlist. To their own chief they are wholly loyal-the Zemindar of Ramnad, the Rajah of Pudakotta, and others-but of the British Government a large number of them know absolutely nothing.

It seems somewhat anomalous that in our administration they should be amenable to Sanscrit (Aryan) Hindu law, which is as foreign to them as it would be to Maoris, though it is supposed to represent their customs (Heaven knows why !); and as to restrictions on the liberties of others, that they should be on a par with the mildest Bengali Baboos, who are about as near in kindred and character to them as are the Chinese. Hence their freedom to indulge in plunder.

M. Topinard places the Dravidian thirtieth on his list of races, according to stature. This is, I think, too low. The Kullen and Maravan should come about twentieth, or not much lower. Active, strong, and muscular; quick, eager, 


\section{Early Ruces of South India.}

and energetic of speech and gesture; skin very dark; Maravans are fairer. Ordinary dress, a small loin-cloth, and turban. Men wear a couple of ear-rings in each ear.

The Kullens of Madura are divided into East-country Kullens and West-country Kullens. Those of the west say they were separated from the others by the King Tirumal Naik, in consequence of one of their number having stolen something from the palace, of which they were the watchmen.

There are eight tribes in the east, and the same number in the west. Those of the east will not intermarry with those of the west, but they will eat together. It is curious that the South India Railway now divides them.

The tribes of the west first. The Paramalli, Nadu Kullens are divided into eight tribes-perhaps tribe is not the right word. The divisions may be inter-tribal. I am unable to decide. The names not exclusively Tamil, or even Dravidian in origin, are those of the head village of each tribe, or whatever it is. It is important, because thereon depends whether their marriage is exogamous or otherwise. A man or woman of one of the eight tribes must marry into one of the others. Men marry between 15 and 25, girls over 10. Bridegroom goes with music to the bride's village, bearing material for a feast, and remains there feasting for two days. On the third day he brings the girl home quietly. The marriage token is unique." It is made of twisted or plaited hair of a bullock's tail, or it may be of horsehair. It is tied round the bride's neck by the bridegroom's sister. The bridegroom is bound to provide some article of food for his wedding feast which he has stolen, and this unfortunate necessity sometimes separates him from his bride, the police taking care of him instead.

A woman may leave her husband whenever she likes. The fine idea of the spiritual union of the Hindu marriage is quite foreign to the Kullens, as well as to all the earlier races of South India. So important is this, that I will 
quote from the Madura Manual concerning the Kunuvans, who live in the same tract of country as the Kullens.

"A husband can at any time get rid of his wife by taking her to her parents, together with a pair of oxen, if he be an Eastern Kunnavan, and a vati, or round metal dish, if he be a Western. On the other hand, if the wife dislikes her partner, she may leave him on giving up her golden jewels. The silvern she retains in such case, and may, according to her pleasure, either go back to her father's house or marry another man. In the west, however, she takes with her only such property as she may have possessed at the time of her marriage. Her children must all be made over to the deserted husband; and if she be pregnant when she goes away, and a child be born whilst she is living with her second husband, it must nevertheless be given up to the first upon payment of the expense of bearing it in the east, upon mere demand in the west. In this way a woman may legally marry any number of men in succession, though she may not have two husbands at one and the same time. She may, however, bestow favours on paramours without hindrance, provided they be of equal caste, with her. On the other hand, a man may indulge in polygamy to any extent he pleases, and the Western Kunnavans keep several wives and servants, particularly for agricultural purposes."

Sati never obtained here, except among the Aryan races. A Kullen woman leaving her husband must return the present (corresponding to the oli of the Wadders, and others) which he gave her when he married her; and when this has been done the discarded husband is treated to a feast. A second or third marriage involves little ceremony - a few family friends to be feasted, and a new marriage token to be tied. There is no compulsory widowhood, as' among the Hindus; a brother-in-law, or any man she fancies, supplies the place of the deceased husband. A curious polyandrous arrangement obtains, though it is, not always admitted. Mr. Nelson thus describes it in his 
Manual of Madura: "Assigning a woman as wife to 10 , 8,6 , or 2 husbands, who are held to be the fathers jointly and severally of any children that may be born of her body. And when such children grow up, they call themselves the children of 8 and 2 , or of 6 and 2 , or of 4 and 2 , not of Io, or 8, or 6 fathers."

A remarkable fact concerning the West-country Kullens is that the boys are circumcised between 7 and 12 . It has bcen said that this practice is a relic of the Mahomedan invasion 230 years ago. With this I do not agree. For what purpose did they acquire it from an alien race, for whom they. felt nothing but hatred? The Mahomedan influence here was never strong. Like all the earlier races, the Kullens cling to their own beliefs and customs, and are strongly averse to any outside intervention. Even our stit
sit conceivable that this uncommon rite, practised by no other non-Islamic community in the country, was seized on and perpetuated by them, while remaining impervious to every other influence of the Mahomedan religion. If, as seems probable, circumcision is a mark of fealty to a god, it may be said they required no such mark, for they have one of their own. Every man's arm, over the deltoid, bears two or three scars made with a sharp stone, in boyhood, for the purpose, so they have told me, of enabling their god to ecognise them when they pass behind the veil.

The East-country Kullens do not observe circumcision; nor do the Maravans; nor the Ahambadiyans. The Westcountry Kullens say, "We have always done it, we don't know why."

Ordinary quarrels, and cases of personal injury, are settled by a little court, of the caste-folk; murders, too, are often compromised in this way, without reference to the police-courts. For wounding another, a man is made to pay a few rupees-" for treatment of the wound" which he inflicted. If the injury is so serious that the man may. die, it is decided that if he dies within a certain number of VOL $\mathbf{r}$. 
days, the man who inflicted the injuries shall pay 70 pons, or $157 \frac{1}{2}$ rupees; in the case of a woman, the fine is exactly half. But if death takes place after the period named, it is understood that the cause thereof was some other than the wounds, and there the matter ends. This kind of compromise, once the rule, is dying out.

The East-country Kullens are recognisable easily by their heavy ear-rings, which drag down the ear-lobes to as much as two inches, or even more sometimes. This kind of deformation of the ear is common in South India, but I have never seen it among men, the East-country Kullens excepted. The dragged-out, attenuated ear-lobes are often torn in anger.

The use of a kind of bomerang is peculiar to the Eastern Kullens. "Crooked stick" they call it. It does not revert to the thrower. A practised hand can cut down a plantain-tree twenty to thirty yards off with it. It is used for knocking over small game, by breaking the legs, usually. Throwing-sticks are not uncommon, but only among the Kullens do they take the shape of the bomerang. In Mysore, a corkscrew-shaped stick about the length of a walking-stick is used by the hunter-caste community. As it revolves, the ends strike the ground, the curves strike the animal, which would be untouched were the stick straight.

The Eastern Kullens have a way of hunting the wild boar which deserves mention, as it is quite unique. A wide semicircle is formed of men standing in pairs, at intervals, and the animals are driven towards them. One man holds a spear, the large head of which is set at a small angle from the line of the shaft. His comrade holds a short stabbing-spear. The driven boar, the most dangerous and fiercest animal of the Indian jungles, charges straight at the first pair he sees. The two men stand perfectly still, and the boar's neck is received on the bent spear. The boar jerks its head up, burying the spear (here the bend comes in) to the flange. The second 
man drives in his stabbing-spear, and the boar is killed at their feet. Those who know what the charge of an Indian boar is, will appreciate the nerve and courage required for this form of sport. People who do this sort of thing for amusement are neither dull nor inert.

The Eastern Kullens have their songs and dances in social as well as religious festivities.

What they call dancing in Kummi is common. Now the men, now the women, perform separately, those who are out, looking on. Stepping or jumping they go round and round while singing a chorus to a verse given out by one. At each verse all stoop forward and clap hands; then round and round again. It is an uncommon form of amusement in South India, where people are rarely aroused to much activity except under religious excitement. Dancing is usually done by proxy. When these people are fully aroused by religious high pressure, as during the Aligiri Festival in Madura, their frenzy is boundless. They dance and leap for days together-it seems-yelling, and laughing, and singing, and lashing themselves with whips.

In the south of the tract where we find the Eastern Kullens, not very far from Ramnad, close to holy Ramêsbaram, one of the most sacred shrines of the BrahminicalHindu religion, visited by crowds of pilgrims from every part of India, we meet the Konddya Kothai Maravans, who observe a very remarkable ceremony in connection with their dead. An unmarried boy or girl is burjed without any ceremony immediately after death. When a married person dies, a death-message is sent to all relatives, who assemble as soon as possible, and in their presence the body is carried outside the house. After mourning and weeping, the corpse is catried on a bier prepared for the occasion, to the spot where the dead are disposed of. There is music by the way. The body is burnt. The man who lit the pyre is shaven. Next day there is the Karmantram ceremony. The relatives go to the place where 
the corpse was burnt, heap up the remains of the burnt bones, and pour thereon water and oil-seeds, and break an earthen pot. They eat that night in the deceased's house. Cooked rice and incense are offered to the spirit of the deceased.

But whenever funds are wanting to perform the Karmantram ceremony as above, the strange procedure is this. No death-message is sent. The corpse is wept over, and then carried to the local "God's Acre" on an arrangement like a ladder. A grave is dug, and the corpse is placed therein. The son or heir throws in some earth, and the grave is filled up. The Karmantram ceremony may be performed any time within the lifetime of the son or heir, whenever he has sufficient money for it. A corpse without kith is never treated to this ceremony. A Monday is fixed for the postponed performance. Relatives are informed by message. They come, and are fed under a shed, much the same as is enacted for the Wadder marriage. In the evening, a bier, followed by all the relatives, is carried with music to the spot where the corpse was buried. The deceased's wife's brother digs up the corpse, removes the skull, which he washes and smears with sandal-wood powder and spices. This man, the brother-in-law of deceased, seats himself on the bier, holding the skull in his hand, and is carried back to the shed in front of deceased's house. No music. The skull is set down, and all the relatives weep and mourn over it until the next day at noon. The following twenty-four hours are given over to drunken revelry. Then the brother-in-law again sits on the bier, skull in hand, and is carried back to the grave, with music. The son or heir of deceased there burns the skull and breaks an earthen pot. The relatives go home, bathe, and feast together. This custom obtains also amongst the Pullers, who are, doubtless, amongst the earliest existing inhabitants of the country, hills or plains.

Eating and feasting in presence of the dead we find in 
other communities in South India, but it is not common. This strange form of it is quite unique. Of course, we have another form of it not far from here-in Irelandwhere the feasting seems to be more drinking than eating. Everyone entering the room bends over the corpse and drinks a glass of whisky to begin with.

I have said nothing of the religion of the Kullens. The Brahminical religion, the worship of Siva and Vishnu in their endless forms, incarnations and so on, is very largely influenced by the more primitive cult which underlies it throughout the Presidency. The higher seems to have had little or no effect on the lower, but the lower has had considerable influence over the higher.

As we go south we find the lower and, I believe, earlier cult becoming more distinct, and in the extreme south it is most separated. The profound influence of this lower cult, in the south, cannot be overlooked by the most casual observer. But it is not so easy to say, "it is this," or "it is that," more especially when we are estimating a people whose habit of thought is utterly different from our own.

What is commonly (in my opinion, wrongly) called Demonolatry finds its strongest expression in the southernmost district-Tinnevelly, which, by-the-bye, contains more Christians than the whole of India put together. Every image of a goddess is sword in hand, and doing something bloody; eating her children, usually, or a child in one hand as if being eaten, another at her feet about to be eaten. Perhaps it is in Tinnevelly that the goats have the worst time of it. During certain festivals they are sacrificed by the thousand to the deities of the lower cult.

I thank you all for your kindness in having listened to me. Whether you all believe in the power of folk-lore and the help it promises to give us concerning the earlier part of man's history, you must feel that intimacy with uncultured man is otherwise beneficial and helpful towards 
better comprehension of the highly cultured, whose life seems to be more and more artificial.

But whether or not, in comparison with the average man of any highly cultured community, to a much greater and wider degree uncultured man is himself, and therefore worth studying.

Mr. E. PEACOCK drew attention to the following extract from Palmer's History of Wrexham.-P. 123.

The gentleman spoken of died in 1883, aged 59. Though an inhabitant of Wrexham for many years, his birthplace was Cefn, near St. Asaph :-

"I have heard the following story of Mr. John Foulkes, sen., that if in his walks a magpie crossed his path, he would make with his stick the sign of a cross upon the ground, and say, 'Devil, I defy thee.'"

Miss BURNE communicated the following notes on present Fifth of November observances in the South of England:-

At Hastings I saw placards announcing the grand procession which would pass through the town on the occasion, carrying effigies (if I remember rightly), and winding up with a bonfire.

At Rye I saw similar placards, announcing the intended doings of the "Borough Bonfire Boys", the route to be taken by the procession, and the place determined for the bonfire, in which the effigies would be consumed, and warning all persons against giving anything towards the funds for the bonfires if not solicited by the authorised "Bonfire Boys".

At Folkestone I saw the procession itself, on Monday, the 6 th inst. It consisted of carts or waggons (cars they were styled), decorated, and containing tableaux vivants contributed by the different Friendly and other Societies in the town. Thus, the Ancient Order of Druids sent a party 